\title{
Church Ethical Values in Good Governance and Entrepreneurship in Nigeria
}

\author{
Osaji Jacob Olasupo \\ Department of Religions, University of Ilorin, Ilorin, Nigeria
}

Email address:

jacobosaji59@gmail.com

\section{To cite this article:}

Osaji Jacob Olasupo. Church Ethical Values in Good Governance and Entrepreneurship in Nigeria. Humanities and Social Sciences. Vol. 7, No. 6, 2019, pp. 191-201. doi: 10.11648/j.hss.20190706.12

Received: October 15, 2019; Accepted: November 19, 2019; Published: December 4, 2019

\begin{abstract}
This research explores the impact of the Church ethical values on the governance and the development of entrepreneurship in the context of Nigeria nation. Entrepreneurship has been identified as a major source of employment, economic growth and innovation. As a result, entrepreneurship has captured the attention of increasing number of scholars in various fields including the Church. The Bible is concerned with the economics of the poor and their well-being. A possible way for Christian to represent the God's plan for earth is to be entrepreneurial, starting business organization rooted in the desire to see the gospel transform the society. For example, Proverbs 6:9 challenges the poor by asking them to awake and go to work. Frost, the director General of the British Chamber of commerce indicated that "Thriving successful business are the lifeblood of prosperous communities. It has never been more important to support the next generation of wealth creating entrepreneurs particularly in these challenging economic times". The church needs entrepreneurs, people who hate the status quo by challenging the norm, people whose greatest fear is the feeding of being stuck right where they are for the rest of their lives. Challenging the status quo is where entrepreneurship begins. The church in Nigeria realized that, the government cannot run the race alone, hence she (the church) becomes partners in progress in running a good governance with advancing entrepreneurship in developing Nigeria. It is against this backdrop that the study seeks to examine the cooperation of the government, the church and entrepreneurship in Nigeria. The study applied analytical methods for its findings.
\end{abstract}

Keywords: Governance, Leadership, Church, Entrepreneurship, Growth and Development

\section{Introduction}

Governments nationally and internationally are encouraging new entrepreneurs and new entrepreneurial business opportunities. Citizens are encouraged to become "out-of-the-box" thinkers, people who identify opportunities and apply their talents to overcome obstacles in order to develop their ideas into new business ventures. Entrepreneurs need to reframe the current recession as an area of business opportunity for all. They must release their innovative and creative ideas around the world and inspire solutions that will tackle issues ranging from poverty to unemployment and climatic change.

It is the fundamental precept of the Christian faith that God calls not only ministers and other spiritual workers, but everyone to specific roles in His kingdom. Christian entrepreneurs must realise that their calling is to establish and lead business organizations that are designed to achieve positive results in the secular world. Christian entrepreneurial businesses differ from secular businesses because Christian entrepreneurs believe they do business while being guided by Christian principles and the Holy Spirit. Their goal is to develop a business that blends business excellence and entrepreneurship with Christian, biblical and theological perspectives.

The decision to become self-employed may stem from the push effect of unemployment or from pull effects induced by economy producing entrepreneurial opportunities. Reynolds, Bosma, Autio, Hunt, de Bono, Servais, Lopez-Garcia and Chin [1] distinguishes between "opportunity-based" and "necessity-based" entrepreneurship. Opportunity-based entrepreneurship involves those who choose to start their own business by taking advantage of an entrepreneurial opportunity. Necessity-based entrepreneurship involves people who start a business because other employment options are either absent or unsatisfactory [2]. 
Anderson argues that it is the fundamental precept of the Christian faith that God not only calls ministers and other spiritual workers, but everyone to specific roles in His kingdom. Christian entrepreneurs must realise that their calling is to establish and lead businesses that are designed to achieve positive results in the business world [3]. Christian entrepreneur businesses differ from secular businesses because they do business while being guided by the Holy Spirit as indicated in Ephesians 2:8-10; John 15:16a and 1 Corinthians 12: 12-18.

According to Desai \& Klapper quoted in Friedman, entrepreneurs in developed countries have easy access to incentives that will help to reduce the burden of entrepreneurial [4]. Friedman pointed out that the policies of certain countries and government directives can either enhance or hinders entrepreneurship [5]. For example, China, over the last decade monitored the movement of her policies towards a free market economy in some sectors of her economy and these changes have brought increase in her entrepreneurship. According to the World Economic Forum (WEF) America rose to second in the entrepreneurship ranking. This is partly due to lack of good economic policies and weak productivity growth that have affected rival countries such as China and Europe. However in Nigeria, government has come to appreciate entrepreneurship as one of the key factors that can help the country to achieve economic growth. Onah observes that governments have realized that the mechanism to development lies in the productive capabilities of entrepreneurship through creation of employment, achieving economic growth, adopting new technologies and innovation capabilities [6].

The importance of entrepreneurship cannot be overemphasized, as it is part of mechanism to propel the wheel of national development which leads to growth in the economy through the adoption of modern technologies coupled with good business envirolment which result to economics of scale and help to reduce the rate of youth unemployment. Since Nigeria independence in 1960, the leadership of Nigeria have shown great concern for the youth unemployment by introducing series of schemes and projects such as Better Life Programme (BLP), Operation feed the Nation (OFN) National Poverty Eradication Programme (NAPEP), Youth Enterprise with innovation in Nigeria (YOUWIN) etc. by instituting agency such as small and medium enterprises development agency to stimulate, monitor and coordinate the development of the every sector. To serve as mechanism for rural industrialization, poverty reduction, job creation and enhanced livelihoods link. But in spite of these initiatives, the spate of entrepreneurship in Nigeria is still below expectation considering the percentage of the unemployed youths ${ }^{5}$. It is against this backdrop that the study seeks to examine the relationship between governance and entrepreneurship in Nigeria.

\section{Entrepreneurship}

According to Asogwa and Anah the word "entrepreneur" is derived from the French verb entreprendre which means to undertake. Economic scholars from time of Adam Smith, through the neoclassical era, the English Economist, the American Economist down to the German School all have their various perspective of the role and function of entrepreneur in economic development [7]. There is agreement however that creation of wealth is not a function of land, labour and capital alone. While the importance of these basic productive factors is recognized, more important is the role of the entrepreneur or the organizer. Schumpeter stresses that entrepreneur is the mechanism through which economy leaves static equilibrium, based on the combinatorial capabilities of entrepreneurial individuals [8]. Knight observes that entrepreneur changes uncertainty into a calculable risk [9]. Shane and Venkataraman quoted in Braunerhjelm assert that entrepreneurship is defined as a person responsible for consequences opportunities to produce future goods and services that are discovered, evaluated and exploited [10]" Odu quoted in Fadeyi, Oke, Ajagbe, Isiavwe and Adegbuyi suggest that employment policies and programmes should have wider and integrated approach with interventions across multiple sectors at multiple levels, by that the entrepreneurial policies will have impact on the economy [11].

Agada and Pius conducted a research on Entrepreneurship Education: A Prerequisite for sustainable National Development. Library research technique was employed in gathering data [12]. The study reveals that entrepreneurship development can help in achieving selfemployed, self-reliant and contribute immensely to the growth of national economic and social development. The study recommends that government should create good businessenvironment that is devoid of insecurity for entrepreneurship to thrive favourably leading to increase in foreign and domestic investments.

\subsection{Entrepreneurial Activities and Perspectives of the Entrepreneurs}

Entrepreneurship helps to achieve growth in the economy most especially in a country where good governance is maximized. According to Global Entrepreneurship Monitor [13] about 54\% (i.e 80 million people) of those involved in creating and growing new firms claimed that they were pursuing a business opportunity for personal interest, often at the same times they were working in a regular job. These efforts are referred to as opportunity entrepreneurship reflecting the voluntary nature of participation. In contrast about $43 \%$ (i.e 63 million people) reported they were involved because of they had no better choices for work such effort is referred to as necessity entrepreneurship reflecting to the individuals perception that such actions presented the best option available for employment but not necessarily the preferred option.

According to Timmons and Spinelli's defined Entrepreneurship as a way of thinking, reasoning, and acting that is obsessed with opportunity, holistic in approach, and leadership balanced [14]. Entrepreneurship results in the creation and realisation of value, not just for owners, but for 
all the stakeholders. At the heart of the entrepreneurial process is the creation, recognition and initiative to seize these opportunities. It requires a willingness to take risks - both personal and financial - but in a very calculated fashion in order to constantly shift the odds of success, balancing the risk with the potential reward. Typically, entrepreneurs devise ingenious strategies to marshal their limited resources. To get the best result from his goal, he sets the following attributes as his target.

\subsection{The Core Attributes of Entrepreneurs}

Timmons and Spinelli identified the core desirable attributes of the entrepreneur focus are as follows.

\subsubsection{Commitment and Determination}

Entrepreneurial attributes like commitment, tenacity and determination to overcome obstacles and compensate for their venture's weaknesses.

According to Dalimunthe, Deakins and Freel. Entrepreneurs seek to overcome hurdles and complete the job at hand. They are disciplined and persistent [15]. They are able to commit and recommit quickly. They are intensely competitive in achieving goals and they love to win. Entrepreneurs are also realistic in recognising what they can and can't do. They know how and where they can get help to solve very difficult tasks.

\subsubsection{Leadership}

Most successful entrepreneurs are experienced leaders. They are usually skilled in the tech- nology and the marketplace in which they compete. They have sound general management skills and have a strong internal locus of control. They are patient leaders, capable of managing for the long haul. They have the vision to build a substantial enterprise that will be relevant to the world while realising a capital gain. This requires patience to stick to the task for five years or more Timmons and Spinelli; Johannsen.

\subsubsection{Opportunity Obsession}

Successful entrepreneurs are usually not inventors. Inventors often become obsessed with their ideas. Most successful entrepreneurs are creative, but are obsessed with the opportunity instead. They allow the customer and market to guide the creation of the product or service Stokes, Wilson and Mador.

\subsubsection{High Tolerance of Risk, Ambiguity and Uncertainty}

Leaders are expected to function in environments characterised by information overload, environmental complexities and ambiguous tasks. Coping with ambiguity and uncertainty are central leadership competencies. Ehrlich, Meindl and Viellieu [16] reported that "leaders are seen as the causal forces which determine the fate and fortune of organisations". Their successes were positively correlated with their tolerance for uncertainty. People with a high tolerance to ambiguity tend to be seen as innovators. The characteristics of innovators are:

Innovators are individuals who think and approach tasks from unsuspecting angles. They can be seen as undisciplined and unpredictable but have the ability to discover problems and discover less consensually expected avenues of solutions; and They act as catalysts in settled groups. They are sometimes seen as abrasive, ingenious, unsound and impractical when they are creating dissonance. They appear to have low self-doubt and will not need consensus to maintain conviction in the face of opposition. They provide the dynamics to bring about periodic change, without which institutions tend to stagnate.

\subsubsection{Creativity, Self-Reliance and Adaptability}

New ventures require adaptive forms of organisation that respond quickly and effectively to change. Successful entrepreneurs have the ability to conceptualise issues and function in this environment. They willingly put themselves in situations where they are responsible for the success or failure of operations. They take the initiative to solve problems or fill a vacuum where no leadership exists.

Self-reliance was originally defined as "the attitude of being self-employed, whether inside or outside an organisation" and was later modified to "the ability to actively manage one's work life and learning in a rapidly changing environment" Waterman, Waterman and Collard [17]. Self-reliance contains some useful entrepreneurial traits and principles which include the following:

The personal responsibility dimension fosters a feeling of competence and control over one's own life. It helps the entrepreneur to cultivate his own resources to solve problems. Taking personal responsibility encourages entrepreneurial thoughts as to what kind of career would be most satisfying, rather than just reacting to environmental opportunities;

Careers are becoming more specialised. It is critical to stay current through continuing education programs and relationships with mentors. Coaching entrepreneurs to create a career development plan can prevent career stagnation and help them thrive in a changing marketplace Waterman, Waterman and Collard, and Entrepreneurs must be flexible and willing to stretch beyond the boundaries of their job descriptions. The most successful entrepreneurs will be those who can best accommodate the changing needs of their environment while keeping a clear sense of self actualisation and their life's direction.

The majority of entrepreneurs are lateral thinkers. This capability is found in a phrase coined by Edward de Bono cited in Sloane, as a counterpoint to conventional thinking [18]. Lateral thinking involves looking at the problem from new directions. De Bono cited in Sloane, 2009 defines the four main traits of lateral thinkers as:

The ability to recognise polarising and unconventional ideas; The ability to search for different ways to look at problems;

A relaxation of the rigid control of vertical thinking; and The use of misinformation and chance can lead to epochal discoveries.

Most businesses' dominant ideas polarise their view of the world. Asking 'What if?' is a lateral thinking technique that 
helps business explore new possibilities and challenge assumptions in the same way. The 'What if?' question could stretch every dimension to the point of being ridiculous, stimulating lines of enquiry by testing the rules, dominant ideas and boundaries that are assumed to apply to a problem.

The common theme is that someone with a curious mind sets out to investigate things. When something unusual happens they study it and see how it can be put to use. When entrepreneurs are looking for new ideas and fresh ways to do things, a random input can help them onto a new path.

\subsubsection{Motivation to Excel}

Successful entrepreneurs appear to be driven by a desire to compete against their own self- imposed standards. They seek out and respond to the challenges inherent in start-up enterprises. Entrepreneurs set high goals to focus their energy from the challenges of creating and building enterprises. High goals enable entrepreneurs to focus their energy and define priorities that provide the measures of their performance. Money is seen as a tool rather than the object of the business game. Successful entrepreneurs insist on the highest personal standards of integrity and reliability. These ethical standards are the glue that bind successful personal and business relationships and make them endure.

\section{The Church Entrepreneur}

Nel described how God established the evangelists, the pastors, the teachers, the prophets and the apostles. No one replaced the other or became more important [19]. He appointed individuals with each of the gifts. They had to take their rightful place in the body of Christ. This gifting in church life has counterparts in the business world:

1. The marketplace evangelist uses business as his platform to evangelise customers, employees and suppliers;

2. The teacher acts as teacher to younger and less experienced business people;

3. The pastor offers a place of care and emotional support in the market place; and

4. The prophet in business gives direction.

Nel argued that most Christians in business have not moved past their evangelistic role. The marketplace needs Christian business men and women to become mentors, care-givers, visionaries and entrepreneurs. Nel claimed that the relevant church is everywhere on earth. This includes the market where the plans of God are to be fulfilled. Apostolic thrust is based on preparedness to go into the world, take new ground in unknown and risky places. An apostolic ministry is exciting and nerve-racking; it may come with severe discomfort and even pain. An entrepreneurial spirit is in essence apostolic in nature and the Christian entrepreneur has a wonderful, although sometimes painful calling to fulfill.

\subsection{Called to Make a Difference}

Anderson argued that it is the fundamental precept of the Christian faith that God calls not only ministers and other spiritual workers, but everyone to specific roles in his kingdom. Christian Entrepreneurs realise that their calling is to establish and lead business organisations that are designed to achieve results in the world. Christian Entrepreneurial organisations differ from secular businesses because they do business while being led by the Holy Spirit (Ephesians 2:8-10; John 15:16a; 1 Corinthians. 12: 12-18).

This is not a new idea, but a return by unfulfilled business leaders to the sense of "calling" enjoyed by fellow laity in the U.S. and Western Europe. The goal is to develop a business that blends business excellence and entrepreneurship with Christian Biblical and theological perspectives.

The Bible places emphasis on spiritual gifts. Christian entrepreneurs believed that their gift is the specific position in which God has placed them. They believe that God has given them the opportunity to create a business enterprise which meets the needs of people in the marketplace. Christian business men and women can be even more relevant when they become mentors, care-givers, visionaries and entrepreneurs in their areas of influence. The plans of God are to be fulfilled in their business.

Christian entrepreneurs develop a specific vision of the future because of the position in which God has placed them. This vision creates a very strong commitment in the Christian entrepreneurs to weather set-backs and adversities. Anderson argued that through their relationship with God, the Christian entrepreneur becomes empowered by his vision. Although their motives are often misunderstood, dedication to the unfolding truth of their vision as revealed by God is the guiding premise of their labour (Romans 1:1-14; 2 Corinthians 4:1, 6: 4-10; Galatians 6:9-10).

The Christian entrepreneur knows that entrepreneurial business requires major commitments to be made. Generally, there isn't sufficient information available in order to totally justify decisions. Therefore, the Christian entrepreneur becomes a calculated risk taker, with risk taking based in belief. There is significant Biblical foundation for taking risks. The Christian entrepreneur is drawn to a life of adventure in service, but recognises that the price of the adventure will be occasional failure and set-backs (Genesis 12: 1-12; Acts 21:13-14).

\subsection{Servant Leadership Provides Value to Customers}

Christian vision does not see the entrepreneur against the world; it sees the entrepreneur involving a group of committed individuals to embrace the Godly vision in order to constantly bring new value to the customer. Christian Entrepreneurs put their personal relationship with stakeholders at the top in order to get the necessary commitment.

The Christian Entrepreneur gratefully receives material blessings as the result of successfully developing a business. Material goals are always secondary to the primary calling and vision. The Christian Entrepreneur constantly seeks out strength from his relationship with Christ to stay in line with the vision. The Christian Entrepreneur will refuse to be drawn into the materialistic world because of a strong moral character that is developed over time.

Barbee said "In this most recent research study, we found 
that businesspeople who take religious values most seriously score significantly higher than others in their ethical judgments." A Christian worldview can be seen as supportive of ethical entrepreneurship. This research is consistent with the findings reported by Laura L. Nash Cited Barbee, a Harvard professor, in her book Believers in Business [20]. She interviewed approximately ninety evangelical Christian CEO's of entrepreneurial firms concerning the way they resolved ethical business issues. She reported that the majority of these entrepreneurs seriously attempted to integrate their faith commitments into their difficult business decisions.

Barbee quoted Longenecker that "In fact, we might also apply Martin Luther's idea of God's calling as it applies to secular work. In the light of Luther's teaching, entrepreneurship can be viewed as a noble calling. A calling that permits the entrepreneur and the entrepreneurial organisation to serve God by the service they render to customers and the broader society."

\subsection{The Church and Entrepreneurship}

Weber argued that religion played a big role in motivating people to take up entrepreneurial activities. He claimed that this explained the rise of capitalism in the West. Weber observed that religious groups such as Quakers had strong links with entrepreneurial activity. These activities have played an important role in shaping the activities of philanthropists. The church has always attempted to support economic solutions to poverty and social problems in their communities through entrepreneurial activity.

Weber's thesis about Protestant religion and the rise of capitalism was in part based on the idea that certain elements of religious belief helped shape people's motivations towards business development. Business was regarded as religiously valued endeavour. Weber argued that social networks provide an important context for trust, acceptable norms and expectations of others. Religious identity provides an important basis for constructing a social network in which economic activity is embedded, and in which social exchanges take place [21].

\section{Governance}

The concept of "governance" is not new. It is as old as human civilization. According to Tende, "Governance" means: the process of decision-making and the process by which decisions are implemented (or not implemented) [22]. Governance can be used inseveral contexts such as corporategovernance, international governance, national governance and local governance. Since governance is the process of decision makingand the process by which decisionsare implemented, an analysis of governance focuses on the formal and informal actorsinvolved in decision-making and implementing the decisions made and the formal and informal structures that have been set in place to arrive at and implement the decision. Government is one of the actors in governance. Other actors involved in governance vary depending on the level of government that is under discussion.
In rural areas, for example, other actors may include influential land lords, associations of peasant farmers, cooperatives, NGOs, researchinstitutes, religious leaders, finance institutions, political parties, the military and etc.

At the national level, in addition to the above actors, media, lobbyists, international donors, multi-national corporations, etc. may play a role in decision making or in influencing the decision-making process. All actors other than government and the military are grouped together as part of the "civil society." In some countries in addition to the civil society, organized crime syndicates also influence decision-making, particularly in urban areas and at the national level. In urban areas, organized crime syndicates such as the "land Mafia" may influence decision-making. In some rural areas locally powerful families may make or influence decision-making. Such, informal decision-making is often the result of corrupt practices or leads to corrupt practices.

\subsection{Good Governance}

Good governance has eight major characteristics. It is participatory, consensus oriented, accountable, transparent, responsive, effective and efficient, equitable and inclusive and follows the rule of law. It assures that corruption is minimized, the views of minorities are taken into account and that the voices of the most vulnerable in society are heard in decision-making. It is also responsive to the present and future needs of society.

\subsection{Participation}

Participation by both men and women is a key cornerstone of good governance. Participation could be either direct or through legitimate intermediate institutions or representatives. It is important to point out that representative democracy does not necessarily mean that the concerns of the most vulnerable in society would be taken into consideration in decision making.

Participation needs to be informed and organized. This means freedom of association and expression on the one hand and an organized civil society on the other hand.

\subsection{Consensus Oriented}

There are several actors and as many view points in a given society. Good governance requires mediation of the different interests in society to reach a broad consensus in society on what is in the best interest of the whole community and how this can be achieved. It also requires a broad and long-term perspective on what is needed for sustainable human development and how to achieve the goals of such development. This can only result from an understanding of the historical, cultural and social contexts of a given society or community.

\subsection{Accountability}

Accountability is a key requirement of good governance. Not only governmental institutions but also the private sector and civil society organizations must be accountable to the 
public and to their institutional stakeholders. Who is accountable to whom varies depending on whether decisions or actions taken are internal or external to an organization or institution. In general an organization or an institution is accountable to those who will be affected by its decisions or actions. Accountability cannot be enforced without transparency and the rule of law.

\subsection{Transparency}

Transparency means that decisions taken and their enforcement are done in a manner that follows rules and regulations. It also means that information is freely available and directly accessible to those who will be affected by such decisions and their enforcement. It also means that enough information is provided and that it is provided in easily understandable forms and media.

\subsection{Responsiveness}

Good governance requires that institutions and processes try to serve all stakeholders within a reasonable timeframe. Characteristics of good governance

\subsection{Effectiveness and Efficiency}

Good governance means that processes and institutions produce results that meet the needs of society while making the best use of resources at their disposal. The concept of efficiency in the context of good governance also covers the sustainable use of natural resources and the protection of the environment.

\subsection{Equity and Inclusiveness}

A society's well being depends on ensuring that all its members feel that they have a stake in it and do not feel excluded from the mainstream of society. This requires all groups, but particularly the most vulnerable, have opportunities to improve or maintain their well being.

\subsection{Rule of Law}

Good governance requires fair legal frameworks that are enforced impartially. It also requires full protection of human rights, particularly those of minorities. Impartial enforcement of laws requires an independent judiciary and an impartial and incorruptible police force.

\section{The Role of the Church in Public Issues}

By way of introduction a few remarks about the concept of the church. "Church" can refer to different meanings or levels of being church: it partly refers the "institution" in its formal structures, but at the same time it refers to the individuals - to the members of the church; even in terms of its structures, "church" refers both to local congregations, or a fraternal or circuits of congregations, or regional and national body, or even being members of global forums like the World Council of Churches [23]. Thus, the witness and the activities of the church are both on local and international level, could be part of formal campaigns through official structures, or it could refer to individual members acting within civil society networks and even as members of parliament - representing different parties.

The history of the ecumenical movement (World Council of Churches) and the global fight against apartheid are examples of a global coalition for social justice, for a global social movement. In this sense the church is one of the oldest forms of Globalization in a positive sense, representing views and interests in the world. A common feature of these movements and formal networks, is their advocacy and lobby work to foster a specific agenda: more social justice, more democratic participation, more peace and development for all communities, in all parts of the world - taking sides on behalf of the poor and those excluded or marginalized. Thus, this global agenda of the church was always directed at influencing the public agenda - and in this sense the agenda for social movements, as well as political institutions such as parliaments or elected governments. Sometimes, through specific campaigns, this also include the lobby for priorities in public spending - are resources used in such a way that the poor really benefit, that social justice is advanced?

In Nigeria struggle against corruption has been on increase since our transformation to democracy, there were several national campaigns, e.g. campaigh against poverty eradication, human trafficking, against injustice with regard to the fundamental injustices, of "standing for the truth", against Boko Haram insurgence, a national consultation process to highlight the plight of the poor (poverty alleviation); to highlight the plight of people that suffered in the struggle against Boko Haram insurgence (Truth and Reconciliation process). Thus, the challenge for the church in this regard is to be provocative - to be political, without being bound by loyalty to a specific political party; to analyse economic systems and their consequences, without adhering to one economic theory or ideology; to challenge and question policies that exclude or marginalize specific sections of society; and to challenge the priorities of public spending.

In this regard, by way of example, there are general questions in the current public debate in Nigeria that are prominent: in economic terms - should the state spend so more money on the national assembly members, or why do we buy weapons for billions of naira, whilst we do not have enough fund or for adequate social housing, quality medical services and more affordable education? Churches, must therefore challenge political parties, parliamentary hearings and government representatives with regard to the priorities they set - bearing in mind that these choices and their outcomes are complex. We cannot assume that as the churche we have all the answers to complex policy decisions. What is expected of the churche, is that she should challenge political and economic decisions from the perspective of social justice: decisions on economic policies and priorities for government to be defended in a technical terms - that distribution of social amenities should be done according to societal needs.

Another area where the church can intervene is to see that 
theres is security and life properties. That public officials and political office holders should make sure killing, kidnapping corruptions and vices are stopped in the nation and common people. The church is expected to address these evil acts publicly on the pulpit, in there meetings (Bible Study, Prayer meeting and fellowship meetings for God's intervention. The church should commit herself to finding solutions to the needs of the masses through prayers, consultation with the government on issues of unemployment giving advice and necessary support. Praying to liberate the poor from their daily struggle, to survive and to enjoy relative comfort in life, this could only be achieved through a comprehensive partnership of all sectors in our society the State and Church alike.

The idea of the church working in partnership with the State is not without risk; in fact, many theologians or church leaders warn against the danger of cooption, of being used by politicians who have their own agendas. Although man has the right to criticize government in areas where this may be necessary. This can be done from the heart of the Christian identity. With regard to the delivering of services to the poor, it was emphasized that the church advocates the principle of subsidiarity. This implies formal cooperation between the church and the state to ensure the effective utilization of limited funding and the adding of value to stretch the opportunities for all her citizens.

\subsection{The Church and the State}

According to the Bible, the state is one institution among others - family, church. St. Paul describes rulers as ministers of God (Romans 3:6). This is so because creation and Christ's redemption touches on every aspect of the world, including political things "thrones and dominions or principalities or powers - all things were created through him and for him" (Colossians 1:16). The purpose of the state is described in various ways, in the Protestant tradition typically as the establishment of justice; and in the Catholic tradition as the promotion of the common good. In scripture, the state is seen to function through its leaders, and point to the furtherance of a just society as the main task. "Give the King thy justice, $\mathrm{O}$ God, and thy righteousness to the royal son". "May he defend the cause of the poor people, give deliverance to the needy and crush the oppression!" (Psalm 72).

The biblical view is also that the state has received its authority from God as hinted above. Authority is regarded as social power. The Bible clearly recognizes the need for authority in the social order. It speaks freely of the authority of priests, kings, parents, and masters. In other words as Abraham Kuyper has noted, one never meets the authority of God Himself, but this authority appears in the office of human persons who do not desire this authority as power exercised by one group over other persons but exercise it only as representatives. This authority can be found in many areas and in many forms [24]. When Paul talks of "governing authorities" in Romans 13, he is recognizing that all human authority is derived from God and has the nature of "office", "assignment," "task". It has an implicitly limited character. "There is no authority except from God". Paul further illustrates that this authority must be exercised for the welfare of those subject to it. The person in authority is "God's servant for your good" (Romans 13:3) In light of this, the state and its authorities exist for the good of the citizenry. Politicians are office bearers. They are to execute their executive, legislative, judicial or administrative offices only for the good of the citizenry. This good is public justice. When they conduct themselves in this manner then the state can be said to be exercising good governance.

The Church is the new community brought about by the death and resurrection of Jesus Christ. It is called to be both a sign of God's new rule of Shalom and the instrument of God's purposes of fulfilling that role in the world (Matt. 28:16-20, $5: 13-16)$. The Church acknowledges that Jesus is Lord (John 13:3, Colossians 1:15-20 and that Jesus' Lordship extends over all the earth, even though it is not acknowledged by all the inhabitants of the earth (Romans 8:24f). It is in this sense that we can call the Church a community where the Lordship of Christ is acknowledged, and where the burden of sharing and demonstrating the benefits of his Lordship is high on the agenda.

Christopher Sugden describes the Church's mission in a nutshell as being: "To declare Jesus Lordship over the whole created order, demonstrate what creation looks like when acknowledging its master, summon all people to acknowledge his Lordship and seek ways of ordering the world that best express the present Lordship of Jesus, the King of justice and righteousness, the prince of shalom [25]. The Church's mission must be seen in the light of God's ultimate purpose and plan for mankind and the universe, as revealed in the life, death and resurrection of Jesus Christ. God's plan is that all the created world, people, supernatural powers, natural forces and institutions work in agreement with God's purpose that his sovereignty over all things will be acknowledged and his reign of peace and justice will be realized. The Church is the instrument for furthering God's purposes as revealed in the life, death and resurrection of Jesus Christ. The life and ministry of Jesus Christ reflect Him as one who proclaimed God's righteousness against the injustices of his day and as one who sought to bring about social renewal on the basis of God's reign. In Luke's Gospel (4:18f) Jesus describes his mission as that of bringing good news to the poor, release to the captives, healing for the blind, freedom for social victims and the arrival of the year of the Jubilee in which the renewal of society and the environment as a whole is put into effect (Isaiah 61:1f).

Consequently, Jesus went about healing the sick, liberating many people from the bondage of dehumanizing powers and restoring to them their God-given dignity (John 9:1; Luke 8:26f; Mark. 5:21). He disregarded the social and hierarchical barriers of gender or class, ritual cleanliness or piety which traditionally separated people from each other.

Jesus challenged the authoritarian and patriarchal patterns of leadership within contemporary Judaism and surrounding cultures; and instated that the renewed community avoid cultural and economic patterns that created a chain of domination, maintaining institutionalized injustice. In this 
way he turned social relations upside down and sought to re-establish them along egalitarian lines. He demonstrated these new set of values in the way he called and related with his disciples (Luke 22:26; 1 Corinthians. 1:27). On the other hand Jesus persistently challenged social and economic injustices; and taught the right attitudes towards wealth and poverty. His confrontation with religious and political leaders of His day about injustice; complacence, hypocrisy led to his death. The Church has no other mission apart from that of God as reflected in the life and ministry of Jesus Christ. The Church is the extension of that mission and ministry. It must therefore emulate Christ.

As already illustrated, both the state and the Church derive their mandate from God and are called to serve His purposes by working for the common good - that is, for conditions that promote human dignity, responsible stewardship and fairness in human relations.

In this way, they are complimentary in their roles. When the state, using its instruments of governance creates conditions that are enabling of citizens to enjoy their rights and to exercise their responsibilities in peace; such an environment is also conducive for the Church to preach the Gospel and uphold a life of dignity for God's people it enhances entrepreneurship, economic growth and development of the society.

Although the state through its government is expected to be accountable to the electorate and the Church to her members, both institutions are ultimately accountable to God. Accountability promotes entrepreneurship.

However both the state and the Church being institutions that are managed by human beings, they are subject to going astray and failing to fulfill their divine mandate. Right from the biblical times we read of kings exercising their authority in a manner that oppressed, exploited and marginalized their subjects. Oppression and exploitation will not enable investors to invest in our Nation. When there is no investment, both the church and state will suffer for it.

In Nigeria for example, political leaders have by and large not lived up to the principles and practices that contribute to good governance. This is especially reflected in various political evidence in Nigeria since1966 till today.

1. Human rights abuses characterized by harassment of people having divergent views from those in the regime in power, illegal arrests and detention, disappearances and killings.

2. Mismanagement and plundering of national resources.

3. Undermining the constitutional mandate of national institutions by making them serve personal or group interest as opposed to national interests.

4. Adoption of policies that promote division and undermine national unity and peaceful co-existence within the nation and the region.

5. Deliberate flouting of constitutional provisions.

Since the Church, according to Bishop Okullu, is institutionalized by God "to bring the mind of God to bear upon total human life and contribute to the building of value systems upon which a sound society may be built," it has a responsibility to call the state to order and remind it of its divine calling (John. 5:3; 1 Peter. 1:17; Deuteronomy 10:17-19 and 16:18f; Jeremiah 23:3; Psalm 45:4-8). In this case the state must recognize that the Church has a divine right from God to possess and to use all rights of correction and admonition invested in it without threat or interference from the state [26]. Similarly, when the Church conducts herself in a manner that betrays her mission, for instance the ongoing cases of exploitation of the poor through the money for prayer programs, the state is justified to intervene.

\subsection{Church/Christian Contribution to Good Governance}

1. Earnestly praying for leaders at all levels

Leadership is exercised at various levels and in different institutions. The quality of leadership at these levels and institutions has a bearing on the quality of life that citizens enjoy. Poor leadership at family level, for instance, can nurture children in patterns of behavior which in the long run impact the whole country.

In addition, decision making is a very delicate process which needs the guidance of God, the omniscient. It is for this reason that St. Paul admonished the church, that supplications, prayers, intercessions, and thanksgiving be made for all men, for kings, and all who are in high positions, that we may lead a quiet and peaceable life, godly and respectful in every way (1 Timothy 2:1,2).

\section{Influencing policies}

It is often said that the changes we want to see in society remain wishful thinking till they are translated into public policy. This is the basis of the Uganda Joint Christian Council Parliamentary Program. In 2002 we realized that we were complaining about bad laws and policies at the stage of implementation. We decided to be more strategic, so we appointed two staff members to work with Parliament full time, so that our in-put in the legislative process can be timely.

3. Empowering citizens

The need for empowering the population cannot be over emphasized. Good governance cannot easily be realized except citizens are empowered as noted by Bishop Okullu. He further sais "citizenry that are not participants in their governance, hence, are ignorant of what is going on in government he says "One of the ways in which African politicians succeed in manipulating the people is by keeping them ignorant of their inalienable human rights and liberties bestowed on them by their creator. Constitutions are written, in English or French, and then put safely out of reach of those whom they are supposed to protect".

Okullu also links the lack of awareness of rights to the people's failure to take initiative and participation in nation building.

"They will not be granted participation in decision making unless they demand it and they will not demand it unless they understand that it is their right", he said

The Church in partnership with other civil society organizations can design programs that aim at raising the level of general consciousness in this area of human rights and responsible citizenship. 
4. Contribute to strengthening public accountability

Increasingly, in our society money is becoming the currency of dignity. Consequently abuses of public offices for direct or indirect personal gain are on the increase. This phenomenon hurts not only the economy but it has become a sick system which in the end hurts the poor and punishes those who choose to live with integrity.

The Church should lobby government so that legislation is strengthened to make corruption unprofitable; to increase people's participation in governance and distribution of resources - operationalize the information bill so that information is available at all levels to facilitate monitoring.

5. Giving voice to the voiceless

Marginalization is one of the reasons why we have tension, conflict and even armed rebellions. Often it is not easy for those suffering marginalization to stand up for themselves. Solidarity with those who suffer marginalization, alienation, intimidation, harassment and oppression is one way in which the Church can challenge the state to be accountable.

\section{Recommendation}

Realizing good government in any society is a collective effort, no one institution in society can fulfill it alone, yet each institution by adhering to the principles of good governance contributes to it.

1. The Church must seek to be exemplary. The Church's life must authenticate its prophetic voice. We can address our politicians most effectively when we demonstrate our own credibility:

1) In the management of resources, human, financial, time

2) In the management of diversities in our churches

3) In the way we nurture the ecumenical vision and how we cooperate with other faith groups

4) In the way we are open to scrutiny

5) In our ability to harmonise our voice

6) Our willingness to accept failure and readiness to repent and reform

7) By our actions of love and compassion

8) By our choices and lifestyles.

2. The Church needs to re-evaluate its understanding of church and state relations and relinquish its search for status and protection from the state. While it is commendable for the Church to cooperate with the state, it is important that the Church is not compromised by promises or actual offers of gifts from the state.

The Church needs to discover herself as a pilgrim community (Hebrews 13:13), as a community called to live outside the camp, in the wilderness; away from the wings of security provided by the government. It is not necessary for the Church to work at securing their status or future. There is no need for the Church to give absolute commitment to the state or to any political ideology or economic theory.

3. The Church needs to live up to its 'double-identity'. According to John Stott, "on the one hand the Church is a 'holy' people called out of the world to belong to God.
But on the other, it is a 'worldly' people in the sense of

being sent back into the world; to witness and to serve".

The Church must therefore grasp the vision of God, who is concerned about making everything new. He seeks that individuals are recreated in Christ as well as the whole creation. This re-creation begun with the coming of Christ and it is the responsibility of the Church to further it. This awareness helps the Church to avoid polarization and to hold in tension the spiritual and social dimensions of its mission.

Since realizing good governance is a collaborative effort, let me appreciate the critical role that academia and media can play in promoting good governance.

1. The academe, working through professional groups or as individuals, has the role of contributing to the analysis of trends in society, providing in-depth professional understanding of issues, such as conflict, gender relations, democracy, and justice. Subject-matter experts may also propose alternatives to existing approaches or responses to issues in society. They can contribute to setting the national agenda.

2. The media is often referred to as the fourth arm in a functioning democracy to Parliament, the Judiciary and Executive and has a critical role to play by:

1. Contributing to legitimacy of institutions of governance

For the above institutions to function, they need to enjoy a certain level of confidence within the population. The media therefore have a role to play in contributing to the legitimacy of institutions, which may lead to stability in the country.

2. Engaging society around strategic issues

The media is key in agenda setting, mobilizing and focusing society around critical issues that impact the welfare of communities.

3. Contributing to healthy management of conflicts in society

Conflicts are part of any healthy functioning society. Depending on how they are managed, conflicts can contribute to growth and a deeper understanding of the parties involved, however when they are poorly managed they can lead to discord and violence.

The media may contribute to the resolution of conflicts or may exacerbate those conflicts, depending on how they report them.

\section{Conclusion}

Poverty means oppression and dependency in all aspects of life, socially, economically and politically argues: Christian have a duty to liberate from all kinds of poverty [27]. It is encouraging to know that it is possible for people to be self-reliant because poverty is reducible. The words of Pope Paul VI "God's designs for the human person is that they may develop to fulfillment as every life is a vocation," affirm that no person should live in poverty.

Mair and Marti identify that those who live in poverty are unable to participate in market due to the weakness or complete absence of supportive institutions. It is therefore, 
time now for the church to help her faithful to develop to fulfillment by enabling the poor to meet their basic needs.

Although evangelical churches have tended to maintain more of a spirit of social entrepreneurship, initiating ministries, schools and other nonprofit organizations, still there has not been either the capacity or the focus needed to develop structures and instruction of a scale and scope to address critically important social problems.

The conclusions further suggested that Christian vision sees the entrepreneur involving a group of committed individuals to embrace the Godly vision for the business and to constantly serve and bring new value to the customer. Christian entrepreneurs put their personal relationships with stakeholders at the top in order to get their necessary commitment. The goal is to develop a business that blends business excellence and entrepreneurship with Christian Biblical and theological perspectives.

Giving of entrepreneurial grants by government should not be politicized, but based on sound business plans. Government should ensure that there is provision of infrastructural facilities that will woo investors from all over the world to Nigeria.

It has become clear that good governance has impact on entrepreneurship but the Nigerian government has not done much to ensure that these schemes geared towards self-employment that will reduce unemployment and corruption are supposed to be controlled by the government not the politicians.

\section{References}

[1] Reynolds, P. D., Bosma, N., Autio, E., Hunt, S., de Bono, N., Servais, I., Lopez-Garcia, P. and Chin, N. (2005). Global entrepreneurship monitor: data collection design and implementation. 1998-2003, Small Business Economics 24 (3), pp. 205-231.

[2] Stokes, D., Wilson, N. and Mador, M. (2010). Entrepreneurship. Cengage. Hampshire.

[3] Anderson, B. (1999). Profile of the Christian Entrepreneur. [Online] Available from: http://www.christianentrepreneur.org/resources/index.html. (Accessed on 18 May 2009).

[4] Friedman, B. A (2011) Relationship between Governance Effectiveness and Entrepreneur.

[5] "World Economic Forum: a history and analysis". Retrieved 20 January 2017.

[6] Onah, F (2001) Urban Unemployment Situation in Nigeria in: Ezeani, N Elekwa (eds) Issues in Urbanization and Urban Administration in Nigeria. University of Nigeria, Nsukka.

[7] Asogwa, O. S \& Anah, S. A (2017) Impact of Entrepreneurships Development on EconomicGrowth of Enugu State: A study of Registered Entrepreneurships in Enugu State, Nigeria. International Journal of Economics, Business and Management Research, 1 (2).

[8] Schumpeter, J (1934) Theory of Economic Development: An Inquiry into Profits, Capital, Interest and Business Cycle,
Cambridge, M. A; Harvard University Press.

[9] Knight, F (1921) Risk, Uncertainty and Profit Library of Economics and LibertY http://www.econlib.org/library/knight/knRUP.html.

[10] Braunerhjelm, P (2011) Entrepreneurship, Innovation and Economic Growth: Interdependencies, Irregularities and Regularities in D. B Audretsch, O. Flack, S. Heblich \& A. Lederer (eds.) Handbook of Research on Innovation and Entrepreneurship. 161-213, Cheltenham: Edward Elgar.

[11] Fadeyi, O: Oke, A. O: Ajagbe, M. A: Isiavwe, D. T \& Adegbuyi, A (2015) Impact of Yout Entrepreneurship in Nation Building. International Journal of Academic Research in Public Policy and Governance. 2 (1).

[12] Agada, J. A. A \& Pius, E. J. B (2014) Entrepreneurship Education: A Prerequisite for/Sustainable National Development. Journal of Good Governance and Sustainable Development in Africa (JGGSDA) 2 (3) December, 65-7.

[13] Global Entrepreneurship Monitor (2001) Vanguard Newspaper.

[14] Timmons, J. A. and Spinnelli, S. (2007). New Venture creation. Entrepreneurship for the 21st Century, 7th Edition. Mc Graw Hill. New York.

[15] Dalimunthe, R. (2009). What Makes You an Entrepreneur [Online] Available from. http://ezinearticles.com. (Accessed on 20 February 200.

[16] Ehrlich, S., Meindl, J. and Viellieu, B. (1990). The charismatic appeal of transformational leader: An empirical case of a small, high technology contractor. Leadership Quarterly, 1, pp. 229-248.

[17] Waterman, R. H., Waterman, J. A. and Collard, B. A. (1994). Toward a career-resilient workforce. Harvard Business Review, pp. 87-95.

[18] Sloane, P. (2009). Think Laterally. [Online] Available from http://www.Lifehack.org/articles/management/think-laterally.h tml. (Accessed on 12 February 2009).

[19] Nel, E. (2006). Do business till I come. Instruction to a new business generation. Yahweh Shammah Publishers. Port Elizabeth.

[20] Barbee, B. (1983). Ethics of Entrepreneurship. Baylor Business Review. Baylor University.[Online] Available: http://www.baylor.edu/BBR/index.php?id=27171. (Accessed on 18 May 2009).

[21] Weber, M. (1922). The Theory of Social and Economic Organisation. A. M. Henderson and T. Parsons, New York: The Free Press.

[22] Tende, S. B. A (2013) Government Initiatives toward Entrepreneurship Development in Nigeria. Global J Bus Res, 8 (1) $109-120$.

[23] Russel H. Botman, Good governance "The Role of the church, African Perspective, Stellenbosh University.

[24] Kuyper, Abraham (1998). "Sphere Sovereignty". In Bratt, James D. (ed.). Abraham \Kuyper: A Centennial Reader. Grand Rapids: Wm. B. Eerdmans. ISBN 978-0-8028 4321-0.

[25] Christopher Sudgen "Faith And Modernity (Lynx/Regnum Studies Evangelism, Mission And Development) Seeking the Asian Face of Jesus: The Practice and Theology of Christian Social Witness in Indonesia and India 1974-1996. 
[26] Bishop Okullu "Interview about Institution and the Mind of God 07/06/2015.
[27] Hosea Mpogole (2002) "The Role of the Church on Social Entrepreneurship development in Tanzania" Tumaine: University at Iringa. 